\title{
Lutein Content in Sweetpotato Leaves
}

\author{
Evdokia Menelaou, Armen Kachatryan, and Jack N. Losso ${ }^{1}$ \\ Department of Food Science, Louisiana State University Agricultural Center, \\ Louisiana Agricultural Experiment Station, Baton Rouge, LA 70803
}

\author{
Michael Cavalier and Don La Bonte \\ Department of Horticulture, Louisiana State University Agricultural Center, \\ Louisiana Agricultural Experiment Station, Baton Rouge, LA 70803
}

Additional index words. Ipomoea batatas, macular degeneration

\begin{abstract}
Fresh leaves of 6 sweetpotato (Ipomoea batatas [L.] Lam.) genotypes, 'Beauregard', 'Bienville', L99-35, L00-8, L01-145, and L01-29, were characterized for lutein. Lutein is a carotenoid capable of delaying blindness-related macular degeneration. The content of lutein in sweetpotato ranged from 0.38 to $0.58 \mathrm{mg} \cdot \mathrm{g}^{-1}$ fresh weight. Betacarotene separated from lutein on high-pressure liquid chromatograms and when spiked in pure lutein extract did not interfere with lutein separation. High-resolution electrospray ionization mass spectrometric analysis was used to confirm the presence of lutein in sweetpotato leaves. Stems were also characterized and found not to contain lutein. Our results showed that sweetpotato leaves are an excellent source of dietary lutein and surpass levels found in leafy crucifers. Leaves of sweetpotato and a related species are human food in some countries and may be a major source of lutein for commercial purposes.
\end{abstract}

Lutein and xanthophylls, 3,3'-dihydroxy$\alpha$-carotene and $3,3^{\prime}$-dihydroxy- $\beta$-carotene, have been identified and recognized by various interdisciplinary studies as the major dietary carotenoids present in the human retina and capable of delaying the onset of macular degeneration (AREDS Research Group, 2001; Bernstein, 2002; Bernstein et al., 2004). Age-related macular degeneration (AMD) is a major cause of blindness in the Western world. Risk factors include age, family history, exposure to sunlight, complications of diabetes, and high cholesterol levels. There are therapies, but no curative treatments; most patients with AMD progress to legal blindness. Because standard therapies are limited, there is recognition in the scientific community that nutrition with antioxidants and carotenoids is a meaningful preventive approach against the onset or progression of AMD (Bhosale and Bernstein, 2005; Johnson, 2002; Ribaya-Merchao and Blumberg, 2004; Thurmann et al., 2005).

Lutein is not synthesized de novo and must be ingested from outside sources. Dark green vegetables have been identified as major sources of lutein for human consumption. Major edible sources of lutein, by decreasing order, are kale, spinach, lettuce, and broccoli (Johnson, 2002).

\footnotetext{
Received for publication 11 Nov. 2005. Accepted for publication 11 Apr. 2006. This research was supported by funds from the Louisiana Sweet Potato Advertising and Development Commission (LSPADC) and by state and matching funds allocated to the Louisiana State University Agricultural Center (LSUAC). The cost of publishing this article was defrayed in part by the payment of page charges. Under postal regulations, this article therefore must be hereby marked advertisement solely to indicate this fact.

${ }^{1}$ To whom correspondence should be addressed; e-mail jlosso@agctr.1su.edu.
}

Pratt (1999) indicated that early introduction of lutein in the diet may reduce the severity of AMD. The Age-Related Eye Disease Study Research Group (AREDS Research Group, 2001) found that intake of antioxidants combined with zinc may help reduce the odds of developing advanced AMD. Seddon et al. (1994) suggested that ingestion of $6 \mathrm{mg}$ lutein per day could reduce the risk of macular degeneration by as much as $43 \%$. This concentration would require daily ingestion of approximately $2 \mathrm{lbs}$. of corn, $16 \mathrm{lbs}$. of tomatoes, two salad bowls of spinach, or one bowl of kale. As a consequence, identifying edible sources of lutein, fortifying foods with lutein, and enhancing lutein bioavailability is important, appealing to health-conscious consumers, and timely (AREDS Research Group, 2001; Chitchumroonchokchai et al., 2004; Jones et al., 2005).

Sweetpotato leaves have no current economic value in the United States, although a report indicates that leaves are potential sources of xanthophylls and protein (Walter et al., 1978). No data have been presented to date documenting the range of xanthophylls found in various sweetpotato varieties (Woolfe, 1992). In 1999 to 2001, the United States produced approximately $\$ 214$ million worth of sweetpotato of which only the roots were consumed (Lucier, 2002). The objective of this research was to quantify leaf lutein content in six genotypes of sweetpotato.

\section{Materials and Methods}

\section{Materials}

Sweetpotato leaves from each of the following varieties: 'Beauregard', 'Bienville', L99-35, L00-8, L01-145, and L01-29 were harvested in mid-July 2004 from fieldgrown plants at the Burden Research Station, Baton Rouge, La. The experimental design was a completely randomized design with four replications of each cultivar. The plots consisted of 30-m long rows with $1.2 \mathrm{~m}$ between rows and each row contained 20 plants spaced $0.3 \mathrm{~m}$ apart. Commercial sweetpotato cultural practices were followed as recommended (Boudreaux, 1994). Mostly, the upper three to four open leaves from the apical meristem were harvested from each of three to four randomly selected plants in each replication and bulked. Leaf and vine mass were estimated in September 2003 for 'Beauregard' and 'Bienville' grown in production fields at the Sweet Potato Research Station, Chase, Louisiana. Three random $\mathrm{m}^{2}$ areas of canopy were selected and harvested. Leaves were separated from the vines and both components weighed. These samples were subsequently dried at $85^{\circ} \mathrm{C}$ for $48 \mathrm{~h}$ before a dry weight determination. Plants were spaced $0.3 \mathrm{~m}$ apart and rows were spaced $1 \mathrm{~m}$ apart.

\section{Analytical procedure}

Freshly harvested, petiole-free leaf tissue was frozen at $-18^{\circ} \mathrm{C}$. Frozen leaf tissue was ground in a mortar and pestle and $2 \mathrm{~g}$ were then extracted with $80 \mathrm{~mL}$ of acetone in screw-capped containers at room temperature in the dark overnight. The acetone extracts were filtered through Whatman No. 4 filter paper (Whatman Inc., Florham Park, N.J.) and evaporated in an exhaust hood overnight. The residue remaining on the filter paper was extracted again in $40 \mathrm{~mL}$ of acetone overnight and added to the $80 \mathrm{~mL}$ after filtering. The residuals were saponified with $15 \mathrm{~mL}$ of $10 \%$ potassium hydroxide with gentle shaking overnight. The unsaponifiable compounds were extracted with an ether:hexane (1:1) mixture. The solvent mixture was evaporated in an exhaust hood overnight. Samples were safeguarded throughout extraction from light to minimize degradation. The residue was dissolved in $20 \mathrm{~mL}$ of a methyl tert-butyl ether/methanol (5:95) mixture and filtered through a $0.20-\mu \mathrm{m}$ filter (Nalgene Nunc, Inc., Rochester, N.Y.). Twenty microliters was injected into an YMC $\mathrm{C}_{30}$ carotenoid $\mathrm{S} 3 \mu, 4.6 \times 250-\mathrm{mm}$ high-performance liquid chromatography (HPLC) column (Waters, Milford, Mass.). The flow rate on a Waters 600E using a Waters 717 plus autosampler and Waters 486 Turnable Absorbance detector system (Waters) was $1 \mathrm{~mL} / \mathrm{min}$, separation was isocratic using methyl tert-butyl ether:methanol $(5: 95)$ as the separation mixture, and total separation time was 35 minutes. These procedures were adapted from Lee et al. (2001).

Standard lutein (Sigma Chemical Co., St. Louis, Mo.) was spiked into a sweetpotato carotenoid extract at concentrations ranging from 0 to $200 \mathrm{ppm}$ and the mixture was separated under conditions described previously. A serial dilution of the lutein standard was used for routine quantification of constituent sweetpotato leaf lutein. Similarly, a $\beta$-carotene carotene standard (Sigma Chemical Co.) was spiked into a sweetpotato carotenoid extract to verify that the elution time differed from lutein. Finally, FloraGlo 
lutien (Kemin Industries, Inc., Des Moines, Iowa) from marigold (Tagetes erecta L.) was analyzed and found to be consistent with profiles obtained from standard lutein and our sweetpotato samples (data not shown).

High-resolution electrospray ionization mass spectrometric analysis of sweetpotato xanthophylls was performed on an ABI QSTAR QTOF (Applied Biosystems, Foster City, CA). The samples were dissolved in 1 methanol: 1 water containing $1 \%$ acetic acid and introduced through a syringe pump at a flow rate of $7 \mu \mathrm{L} / \mathrm{min}$ at room temperature. Ion extraction was performed at voltage maintained at $4500 \mathrm{~V}$. The mass spectrometry data were acquired in the positive mode for all xanthophylls.

\section{Results and Discussion}

\section{Analysis of lutein in sweetpotato}

The HPLC profiles for commercial standards of lutein and $\beta$-carotene were found to be dissimilar. Lutein eluted after $16 \mathrm{~min}$. of fractionation, whereas $\beta$-carotene eluted after 3.5 to $4 \mathrm{~min}$. $\beta$-carotene spiked into the lutein extract did not affect lutein separation (Fig. 1). Quantification was validated by a serial dilution of the lutein standard across a range of concentrations. Sweetpotato extracts spiked with lutein and $\beta$-carotene were quantifiable. The electrospray ionization mass spectrometry of the isolated sweetpotato lutein in the region $\mathrm{m} / \mathrm{z}$ between 540 to 580

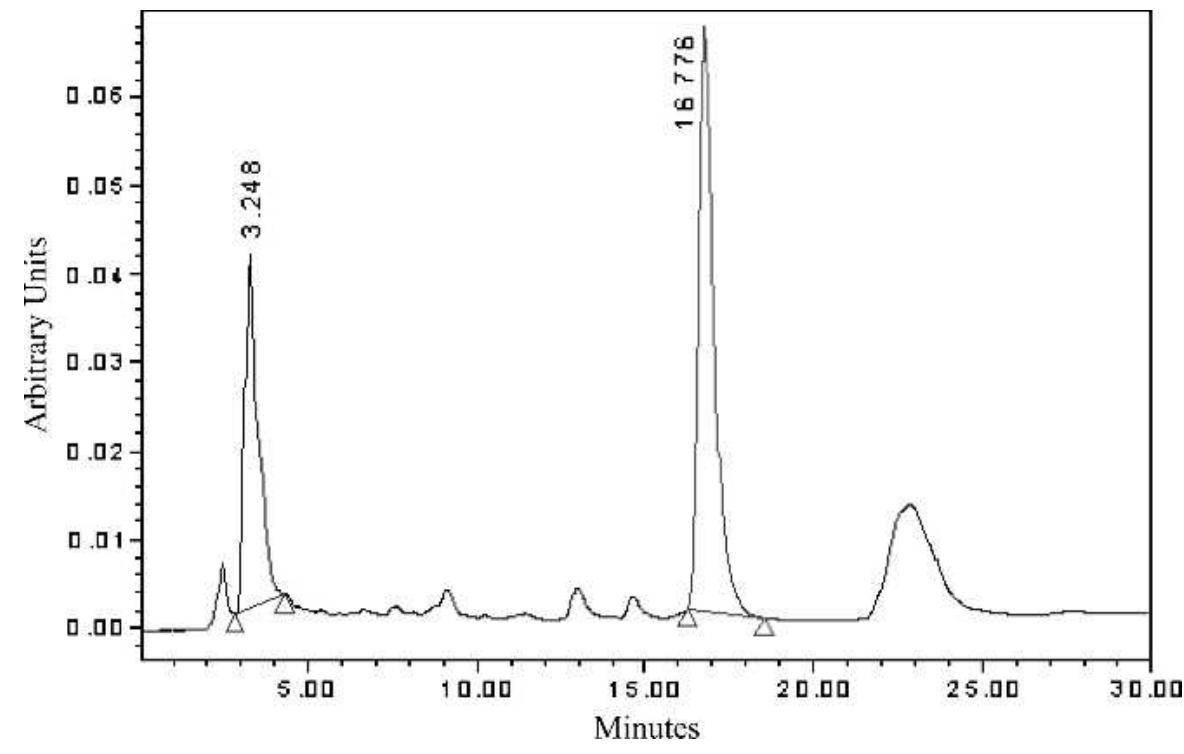

Fig. 1. High-performance liquid chromatography separation of lutein in sweetpotato leaves. Lutein was extracted from sweetpotato leaves as described under "Materials and Methods" and injected into an $\mathrm{YMC} \mathrm{C}_{30}$ column. Lutein was separated isocratically using methyl tert-butyl ether:methanol (5:95) for $35 \mathrm{~min}$.

amu (atomic mass units) indicated the presence of lutein at $\mathrm{m} / \mathrm{z}$ of $568 \mathrm{amu}$. Peaks at 567 and 569 correspond to a loss or addition of one proton, respectively (Fig. 2). Our results are consistent with previous reports of lutein in ethanol and water (Guarantini et al., 2005).
Polyene $\beta$-carotene, with an atomic mass of 536, is known to ionize by a radical process with loss of one or two electrons and thus differs greatly in its profile (Guaratini et al., 2005). These preliminary studies support our underlying techniques to assay lutein in sweetpotato leaf extracts.

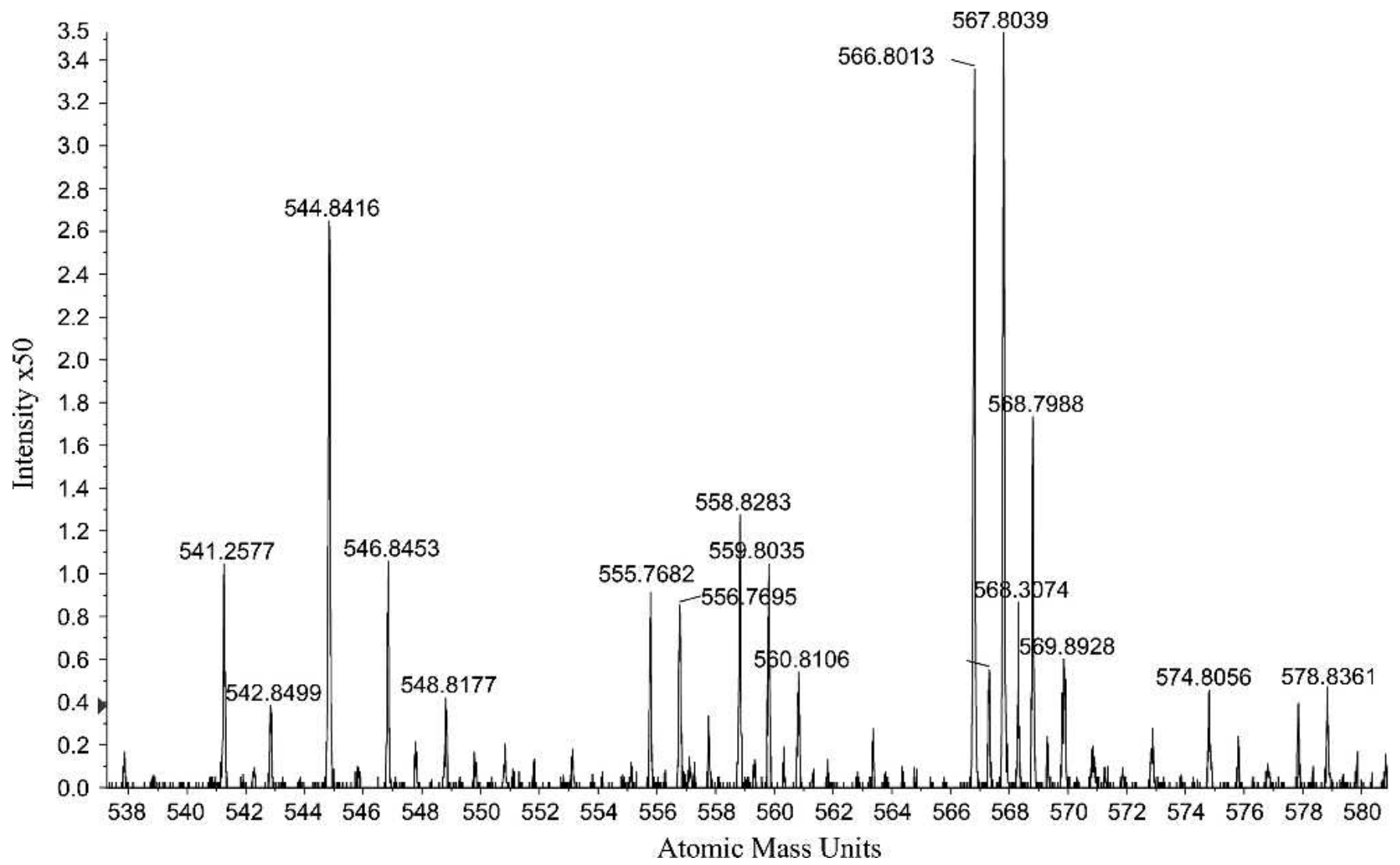

Fig. 2. Electrospray-mass spectrometry of sweetpotato lutein in 1 methanol:1 containing $1 \%$ acetic acid. Lutein in ethanol and water is identified at 567,568 and 569 atomic mass units. 
Table 1. Lutein concentration in sweetpotato leaves in $\mathrm{mg} / 100 \mathrm{~g}$ of fresh leaves.

\begin{tabular}{lc}
\hline Sweetpotato leave variety & Lutein concentration \\
\hline Beauregard & $0.51 \pm 0.04$ \\
Bienville & $0.54 \pm 0.09$ \\
L99-35 & $0.53 \pm 0.16$ \\
L00-8 & $0.44 \pm 0.04$ \\
L01-14 & $0.39 \pm 0.13$ \\
L01-29 & $0.38 \pm 0.10$ \\
\hline
\end{tabular}

\section{Lutein content in sweetpotato leaves}

The six genotypes ranged from 0.38 for L01-29 to $0.54 \mathrm{mg} \cdot \mathrm{g}^{-1}$ fresh weight for 'Bienville,' a difference of approximately $30 \%$ (Table 1). 'Beauregard' and L99-35 had levels comparable to 'Bienville'. A preliminary study in 2003 found similar results (data not shown). Extracts of 'Beauregard' and 'Bienville' sweetpotato vines did not contain any appreciable amount lutein in 2003. These results showed that sweetpotato leaves are among the best sources of lutein among dark green vegetables. Kale has been reported as the edible vegetable with the highest concentration of lutein at $0.38 \mathrm{mg} \cdot \mathrm{g}^{-1}$ (Mangels et al., 1993) followed by spinach at 0.12 $\mathrm{mg} \cdot \mathrm{g}^{-1}$ (Johnson, 2002). Sweetpotato and its relative, Ipomoea aquatica Forsk., are consumed as a leafy vegetable in Southeast Asia and Africa, and this data adds to our understanding of the nutritional value of sweetpotato leaves.

Our data extends that of Walter et al. (1978) who found xanthophylls represented $0.12 \%$ to $0.15 \%$ of dry sweetpotato leaf protein concentrate. The content of total carotenoids, $\beta$-carotene, and $\alpha$-carotene in sweetpotato leaves were $26.79,8.99$, and $0.99 \mathrm{mg} / 100 \mathrm{~g}$, respectively, of dry leaf tissues, showing that xanthophylls were the major carotenoid found in leaves (Mosha et al., (1997).

\section{Biomass estimates}

Total canopy yield on fresh weight basis for 'Beauregard' and 'Bienville' were comparable and estimated at approximately 3000 $\mathrm{kg} \cdot \mathrm{ha}^{-1}$. Leaf yield was estimated at approximately 800 to $910 \mathrm{~kg} \cdot \mathrm{ha}^{-1}$ for 'Beauregard' and 'Bienville', respectively. An extrapolation based on $0.40 \mathrm{mg} \cdot \mathrm{g}^{-1}$ fresh leaf weight and $800 \mathrm{~kg} \cdot \mathrm{ha}^{-1}$ suggests a crude yield of
$320 \mathrm{~g} \cdot \mathrm{ha}^{-1}$. A higher leaf yield and concomitant increase in lutein is possible with high rates of fertilizer, which would promote canopy growth. Lutein from marigold flowers is $0.8 \mathrm{mg} \cdot \mathrm{g}^{-1}$ and represents a common commercial plant source for lutein. The current market price for raw lutein is $\$ 200$ per $\mathrm{kg}$ of 5\% lutein in corn oil from Kemin Foods, Des Moines, Iowa. Extraction protocols will have to be modified to make sweetpotato leaves commercially viable; significantly more solvents are needed to extract lutein from chlorophyll-rich leaves in contrast to chromoplast-rich marigold flower petals.

In conclusion, our study showed that sweetpotato is a rich source of lutein. Its use as a leafy vegetable is novel in most countries and potentially may serve a market niche given its enhanced nutritional status; it is also possible to identify superior leafy vegetable varieties akin to ones used in parts of Africa. The long-term goal is to develop an environmentally sound lutein extraction protocol from sweetpotato leaves.

\section{Literature Cited}

AREDS Research Group. 2001. A randomized, placebo-controlled, clinical trial of high-dose supplementation with vitamins $\mathrm{C}$ and $\mathrm{E}$, beta carotene, and zinc for age-related macular degeneration and vision loss. Arch. Ophthalmol. 119:1417-1436.

Bernstein, P.S. 2002. New insights into the role of the macular carotenoids in age-related macular degeneration. Resonance Raman studies. Pure Appl. Chem. 74:1419-1425.

Bernstein, P.S., D.Y. Zhao, M. Sharifzadeh, I.V. Ermakov, and W. Gellermann. 2004. Resonance Raman measurement of macular carotenoids in the living human eye. Arch. Biochem. Biophys. 430:163-169.

Bhosale, P. and P.S. Bernstein. 2005. Synergistic effects of zeaxanthin and its binding protein in the prevention of lipid membrane oxidation. Biochim. Biophys. Acta 1740:116-121.

Boudreaux, J.E. 1994. Commercial vegetable production recommendations. Louisiana Coop. Ext. Serv. Publ. 2433.

Chitchumroonchokchai, C., S.J. Schwartz, and M.L. Failla. 2004. Assessment of lutein bioavailability from meals and a supplement using simulated digestion and caco-2 human intestinal cells. J. Nutr. 134:2280-2286.
Guaratini, T., R. Vessecchi, E. Pinto, P. Colepicolo, and N.P. Lopes. 2005. Balance of xanthophylls molecular and protonated molecular ions in electrospray ionization. J. Mass Spectrom. 40:963-968.

Johnson, E.J. 2002. The role of carotenoids in human health. Nutr. Clin. Care 5:56-65.

Jones, S.T., K.J. Aryana, and J.N. Losso. 2005. Storage stability of lutein during ripening of cheddar cheese. J. Dairy Sci. 88:1661-1670.

Lee, H.S., W.S. Castle, and G.A. Coates. 2001. High-performance liquid chromatography for the characterization of carotenoids in the new sweet orange (Earlygold) grown in Florida, USA. J. Chromatogr A. 913:371-377.

Lucier, G. 2002. Sweetpotatoes: Getting to the root of demand. Economic Research Service/USDA. Agricultural Outlook/November, 13-17.

Mangels, A.R., J.E. Holden, G.R. Beecher, M.R. Forman, and E. Lanza. 1993. Carotenoid content of fruits and vegetables: an evaluation of analytical data. J. Amer. Diet. Assoc. 93:284296.

Mosha, T.C., R.D. Pace, S. Adeyeye, H.S. Laswai, and K. Mtebe. 1997. Effect of traditional processing practices on the content of total carotenoid, beta-carotene, alpha-carotene and vitamin A activity of selected Tanzanian vegetables. Plant Foods Hum Nutr. 50:189201

Pratt, S. 1999. Dietary prevention of age-related macular degeneration. J. Amer. Optom. Assoc. 70:39-47.

Ribaya-Mercado, J.D. and J.B. Blumberg. 2004. Lutein and zeaxanthin and their potential roles in disease prevention. J. Amer. Coll. Nutr. 23: 567-587.

Seddon, J.M., U.A. Ajani, R.D. Sperduto, R. Hiller, N. Blair, T.C. Burton, M.D. Farber, E.S Gragoudas, J. Haller, and D.T. Miller. 1994. Dietary carotenoids, vitamins A, C, and E, and advanced age-related macular degeneration. Eye Disease Case-Control Study Group. JAMA 272:1413-1420.

Thurmann, P.A., W. Schalch, J.C. Aebischer, U. Tenter, and W. Cohn. 2005. Plasma kinetics of lutein, zeaxanthin, and 3-dehydro-lutein after multiple oral doses of a lutein supplement. Amer. J. Clin. Nutr. 82:88-97.

Walter, W.M., A.E. Purcell, and G.K. McCollum. 1978. Laboratory preparation of a proteinxanthophyll concentrates from sweetpotato leaves. J. Agr. Food Chem. 26:12221225

Woolfe, J. 1992. Sweetpotato, an untapped food source. Cambridge University Press, Cambridge. 